\title{
$\mathrm{CBAPC}$ 바인더로 제조한 인공사 중자의 강도 및 내습성에 미치는 $\mathrm{P} / \mathrm{Al}$ 몰 비와 경화 조건의 영향
}

\author{
오현곤 ${ }^{1,2}$ - 박동국 ${ }^{1}$ - 김양도 ${ }^{2, *}$ - 이만식 ${ }^{1,3, *}$ \\ 1한국생산기술연구원 친환경재료공정그룹 \\ ${ }^{2}$ 부산대학교 재료공학과 \\ 3과학기술연합대학원대학교 청정공정 및 시스템공학과
}

\section{Effect of P/Al Molar Ratio and Curing Conditions of CBAPC Binder on Flexural Strength and Moisture Resistance of Artificial Sand Core}

\author{
Hyeon Gon $\mathrm{Oh}^{1,2}$, DongKook Park', Yangdo Kim ${ }^{2, *}$, and Man Sig Lee ${ }^{1,3, *}$ \\ ${ }^{I}$ Green Materials \& Processes Group, Korea Institute of Industrial Technology (KITECH), Ulsan 44413, Republic of Korea \\ ${ }^{2}$ Department of Materials Science and Engineering, Pusan National University, Busan 46241, Republic of Korea \\ ${ }^{3}$ Department of Green Process \& System Engineering, University of Science \& Technology (UST), Ulsan 44413, Republic of Korea
}

\begin{abstract}
CBAPC (chemically bonded aluminum phosphate ceramic) binders have various advantages, including superior corrosion resistance and strength at high temperature. They are also a non-toxic and eco-friendly material. We investigated an inorganic binder based on CBAPC using artificial sand for casting. The CBAPC binders were synthesized with various P/Al molar ratios from 2.0 to 6.0. Specimens were prepared by mixing the artificial sand and CBAPC binder, and then heat-treating at $260^{\circ} \mathrm{C}$ for $10 \mathrm{~min}$. The prepared CBAPC binders were characterized using TGA/DSC, XRD, FT-IR, and FE-SEM. The artificial sands (Esperal 40, Cps 1) were characterized by XRF, grain size analysis, and FE-SEM. The ultimate flexural strengths obtained for the artificial sands (Esperal 40, Cps 1) were 6.40 and 6.36 MPa, respectively, under the conditions $\mathrm{P} / \mathrm{Al}=4.5$, curing temperature $=260^{\circ} \mathrm{C}$, and curing time $=10 \mathrm{~min}$. The CBAPC_4.5 had higher thermal stability at low temperature than the samples with other P/Al molar ratios. The $\mathrm{AlH}_{2} \mathrm{P}_{3} \mathrm{O}_{10} \cdot 2 \mathrm{H}_{2} \mathrm{O}$ structure formed at $260^{\circ} \mathrm{C}$ exhibited high mechanical strength and moisture resistance with improved flexural strength. The effect on the surfaces of the CBAPC_4.5 coated artificial sands depended on the curing temperature and curing time. We confirmed that the P/Al molar ratio and curing conditions strongly affected flexural strength.
\end{abstract}

(Received August 28, 2019; Accepted November 18, 2019)

Keywords: artificial sand, casting, CBAPC binder, flexural strength, moisture resistance

\section{1. 서 론}

사형 주조는 저렴한 원료와 가공 비용, 높은 생산 효율 성, 대량 생산에서의 우수한 치수 정밀도 등의 다양한 장 점으로 자동차, 조선 및 기계 산업의 복잡한 형상을 갖는 금속 부품을 제조하는데 널리 사용되고 있다 [1-3]. 일반적

- 오현곤: 석사과정, 박동국: 연구원, 김양도: 교수, 이만식: 연구원

*Corresponding Author: Yangdo Kim

[Tel: +82-51-510-3047, E-mail: yangdo@pusan.ac.kr]

*Corresponding Author: Man Sig Lee

[Tel: +82-52-980-6630, E-mail: Ims5540@kitech.re.kr]

Copyright (C) The Korean Institute of Metals and Materials
으로 사형 주조에 사용되는 규사 (silica sand)는 풍부한 자 원과 저렴한 비용으로 주형을 제조하는데 널리 사용되고 있지만 내화도가 낮고, 주의 높은 용탕 주입 온도 및 주물 사 다짐 불량으로 인한 모래 소착 (sand burning), 수축 결함 (shrinkage cavities) 및 기공 (gas cavity) 같은 주조 결함이 발생한다 [4,5]. 주조 공정 중에 주물사의 분쇄로 인해 분진과 산업폐기물에 대한 유리규산이 많이 발생되는 규사의 단점을 해결하기 위한 대안으로 세라믹 성분의 인 공사 (artificial sand)에 대한 관심이 더욱 높아지고 있다. 인공사는 규사에 비해 표면적과 주조 결함을 일으키는 불 순물 함량이 적고, 높은 내화도로 인한 낮은 열팽창율을 가 
지고 있어 파쇄가 적으며, 구형으로 인한 점결제 (binder)의 사용량 감소와 유동성이 우수하여 주형 공간에 조밀하게 충진되어 높은 주형 강도를 발현할 수 있다 [6,7].

사형 주조에 사용되는 바인더는 일반적으로 유기계와 무 기계로 분류되는데 치수 정밀도, 표면 조도 및 주형 강도 가 우수한 유기 바인더는 주로 푸란 (furan) 수지, 페놀 (phenol) 수지 및 레진 피복 모래 (resin coated sand)가 사용된다. 유기 바인더는 우수한 점결력과 주형 강도를 갖 지만 주조 과정에서 벤젠 및 포름알데히드 같은 휘발성 유 기화합물 $(\mathrm{VOCs})$ 이 다량 발생되는 환경 문제를 일으킨다 $[8,9]$. 주조 산업에서 환경 오염을 해결하기 위해서는 $\mathrm{VOCs}$ 가 발생되지 않고, 작업 환경이 매우 친환경적이며, $\mathrm{CO}_{2}$ 가스가 적게 발생되어 주조품의 결함을 감소시킬 수 있는 무기 바인더에 대한 연구의 필요성이 제기되고 있다 $[10,11]$. 무기 바인더는 금속 포스페이트 기반의 CBPC (chemically bonded phosphate ceramic) 바인더, 수용성 염 화합물 기반의 염 (salt) 바인더, 알칼리 실리케이트 수 용액 기반의 물유리 (water glass) 등이 연구되고 있다 $[12,13]$. 물유리는 알칼리 금속을 함유하여 우수한 점결력 과 분산력을 갖추고 있지만 $900{ }^{\circ} \mathrm{C}$ 부근에서 용해되어 고 온에서 낮은 강도를 보인다.

$\mathrm{CBPC}$ 바인더는 시멘트처럼 고화되지만 세라믹에 비해 낮은 온도에서 형성되어 그 구조와 특성은 세라믹에 유사 하다. 화학 결합에 의해 강한 구조를 형성하여 세라믹이 갖는 특성인 고온이나 가혹한 환경에서 우수한 열 안정성 과 높은 강도를 가지며 세라믹에 비해 낮은 온도에서 경화 가 가능한 장점을 가진다. $\mathrm{CBPC}$ 바인더는 화학적으로 결 합된 인산염 세라믹으로 금속 양이온과 인산염의 음이온 반응에 의해 세라믹 결합이 형성되며, 금속 산화물을 인산 에 혼합함으로써 반응이 발생한다 [14,15]. CBPC의 금속 산화물에는 $\mathrm{Na}, \mathrm{K}, \mathrm{Mg}, \mathrm{Zn}, \mathrm{Ca}, \mathrm{Al}$ 및 $\mathrm{Fe}$ 등이 사용되 고 있다 [16]. 다양한 금속 중 알루미늄 $(\mathrm{Al})$ 은 지구상에 서 가장 풍부한 금속 산화물이며 값이 저렴하기 때문에 인 산염 시멘트를 형성하기 위한 유망 재료이다. 알루미늄 양 이온과 인산염의 음이온 반응으로 형성되는 $\mathrm{CBAPC}$ (chemically bonded aluminum phosphate ceramic)는 내 마모성과 생체 내 안정성이 우수하여 인공 치아 및 치근, 인공 관절, 구조 재료 같은 분야에서 사용되고 있다. 또한, 내화물 분야 및 세라믹 코팅제로 사용되어 고온에서의 알 루미늄 포스페이트의 중요성에 대한 깊은 연구가 요구된다. $\mathrm{CBAPC}$ 는 수증기나 환원성의 일산화탄소 분위기 같은 고 온 환경에서의 내부식성이 강하고, 낮은 전기 및 열 전도 성, 우수한 접착성 같은 다양한 장점을 가진다 [16,17]. 따
라서 $\mathrm{CBAPC}$ 를 알루미늄 주조용 바인더로 사용 시 고가 의 세라믹이나 복합재료에 비해 낮은 열처리 온도에서도 우수한 강도를 보이며 유해물질의 발생이 없는 높은 기술 적 중요성으로 그 가치가 매우 클 것으로 예상된다.

$\mathrm{CBAPC}$ 바인더는 고온에서 가열 시 분자간 탈수 축합 반응에 의해 P-O-P 구조를 형성 후 알루미늄에 산소 이온 이 배위되어 P-O-Al-O-P 같은 고분자 구조를 형성하여 강 도를 유지하는 접착성을 갖게 된다 $[14,16,18]$. 인산과 알 루미늄 포스페이트 $(\mathrm{P} / \mathrm{Al})$ 의 몰 비와 경화 조건에 따라 $\mathrm{CBAPC}$ 바인더의 물리화학적 특성이 달라진다고 알려져 있다 $[19,20]$.

본 연구에서는 세라믹의 결합 및 표면 개질을 위해 인산 을 사용하였으며, $\mathrm{P} / \mathrm{Al}$ 몰 비에 따른 바인더로서의 물리화 학적 특성과 이를 이용한 열처리 온도에 따른 세라믹의 강 도 및 내습성에 미치는 영향을 각각 고찰하였다.

\section{2. 실험 방법}

본 연구에서 인공사 Esperal 40 (Lyang Qinlin Trading, China), Cps 1 (Simat International Limited, Hong Kong) 를 사용하였으며, 인공사의 물리화학적 조성은 표 1 과 같 다. 바인더 합성에 사용한 인산 (Phosphoric acid, Purity: 85\%, Grade: EP, Daejung Chemical \& Metals Co., Ltd, Korea)과 알루미늄 포스페이트 (Aluminum phosphate, Grade: CP, Junsei Chemical Co., Ltd, Japan) 시약들은 추가적인 정제없이 사용하였다.

그림 1 은 $\mathrm{CBAPC}$ 바인더의 합성 모식도를 나타냈다. $\mathrm{P} /$ $\mathrm{Al}$ 몰 비가 2.0 에서 6.0 이 되도록 합성하였으며, 시험편의 총 수분 함량 (total moisture content)은 $3 \mathrm{wt} \%$ 로 동일하 게 조절하였다. 예를 들어, $\mathrm{P} / \mathrm{Al}$ 몰 비가 4.5 인 $\mathrm{CBAPC}$ 바인더는 다음과 같이 합성되었다. 실온에서 인산 $80.97 \mathrm{~g}$ 과 증류수 $42.23 \mathrm{~g}$ 을 10 분 교반하였다. 교반된 인산 $123.20 \mathrm{~g}$ 을 인공사 Esperal 40, Cps $12 \mathrm{~kg}$ 에 첨가하여 혼련기를 이용하여 $400 \mathrm{RPM}$ (revolution per minute)으 로 150 초간 혼합한 후, 알루미늄 포스페이트 $19.03 \mathrm{~g}$ 을 첨 가하여 150 초간 혼합하였다. CBAPC 바인더의 함량은 인 공사 중량의 $5 \mathrm{wt} \%$ 가 되도록 준비하였다. 제조된 바인더

Table 1. Chemical compositions of artificial sands by XRF analysis

\begin{tabular}{cccccc}
\hline \multirow{2}{*}{ Samples } & \multicolumn{5}{c}{ Mass fraction of the sample (\%) } \\
\cline { 2 - 6 } & $\mathrm{Al}_{2} \mathrm{O}_{3}$ & $\mathrm{SiO}_{2}$ & $\mathrm{TiO}_{2}$ & $\mathrm{Fe}_{2} \mathrm{O}_{3}$ & etc. \\
\hline Espearl 40 & 71.87 & 16.82 & 5.05 & 4.45 & 1.81 \\
Cps 1 & 44.34 & 43.83 & 1.14 & 7.35 & 3.34 \\
\hline
\end{tabular}




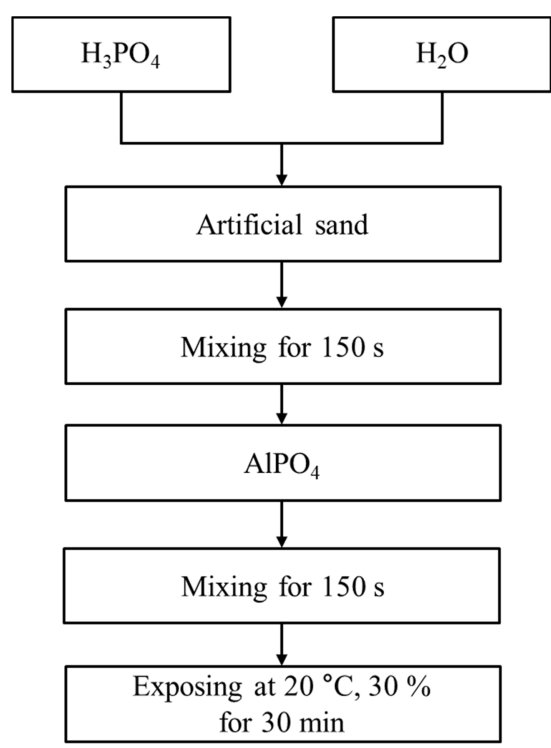

Fig. 1. Schematic procedure for core manufacturing with CBAPC binder.

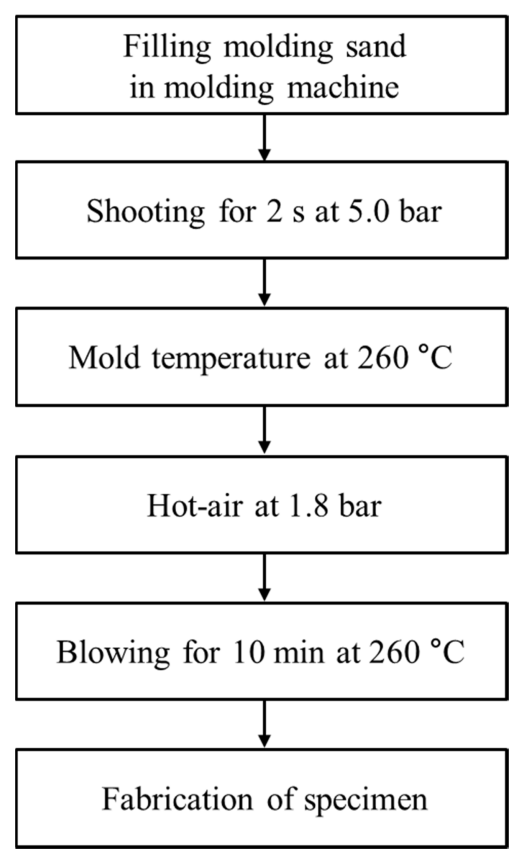

Fig. 2. Schematic diagram for fabricating specimen with CBAPC binder.

는 CBAPC $X(X: \mathrm{P} / \mathrm{Al}$ 몰 비)로 명명하였다.

$\mathrm{CBAPC}$ 바인더의 강도 및 조형 특성을 확인하기 위해 그림 2와 같이 시험 중자를 제조하였다. 금형 및 열풍 온 도는 $260{ }^{\circ} \mathrm{C}$, 주물사의 충진을 위한 슛팅 압력 $5.0 \mathrm{bar}$, 열 풍 압력 $1.8 \mathrm{bar}$, 경화 시간 10 분 조건으로 경화하였다. 그 림 3은 위의 조건으로 시험편 (Length $\times$ Height $\times$ Width: $170 \times 20 \times 20 \mathrm{~mm}$ )을 제조하였다. 모든 시험편은 동일한 환경

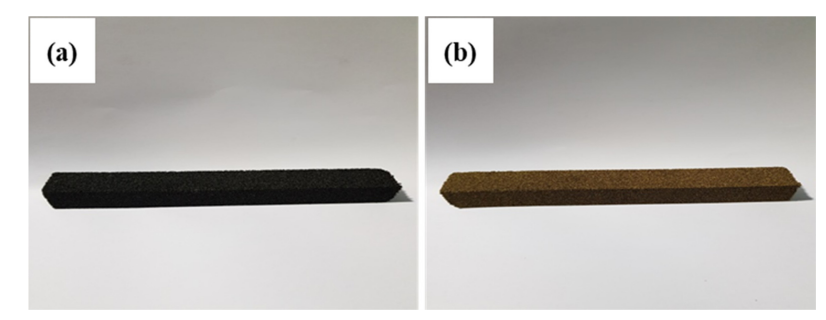

Fig. 3. Photograph of cured specimen prepared by CBAPC_4.5; (a) Esperal 40 and (b) Cps 1.

(온도: $13 \pm 3{ }^{\circ} \mathrm{C}$, 상대습도: $46 \pm 6 \%$ )에서 시험되었다. 제조 된 시험편의 내습성을 확인하기 위해 동일한 조건 (온도: $20{ }^{\circ} \mathrm{C}$, 상대습도: $30 \%$ )에서 10 분, 1 시간 노출 후 항절 강 도 (LCK1205-K500, A\&D Scales, Japan)를 측정하였다. 실험 결과의 재현성을 보장하기 위해, 항절 강도의 각 데 이터 포인트는 최소 5 회 반복하여 $5 \mathrm{~mm} / \mathrm{min}$ 의 속도에서 측정 후 평균 값을 얻었다.

인공사의 화학적 조성을 확인하기 위해 XRF (Zetium, PANalytical, Netherlands) 분석 장치를 사용하였으며, 인공 사의 입자 크기 및 분포도를 파악하기 위해 입도 분석을 수행하였다. 인공사 Esperal 40, Cps $1100 \mathrm{~g}$ 에 대한 입 자 크기 분포를 측정하기 위해, 인공사와 지르코니아 볼 (zirconia ball)을 1:1 비율로 시험 포트에 넣어 $400 \mathrm{RPM}$ 으로 3일간 볼 밀 (GLBM-G, Global Lab., Co., Ltd., Korea) 분쇄하였다. 분쇄된 인공사는 체 (sieve) 분석을 통 해 20 270 Mesh로 분별하였다.

$\mathrm{CBAPC}$ 바인더의 온도에 따른 결정화 및 상변화를 관찰 하기 위해 CBAPC 바인더를 TGA/DSC (SDT Q600, TA Instruments, Japan) 분석 장치를 사용하여, 공기 분위기에 서 $10^{\circ} \mathrm{C} / \mathrm{min}$ 의 승온 속도로 $30 ~ 1400{ }^{\circ} \mathrm{C}$ 범위의 온도에서 관찰하였다. 시간에 따른 $\mathrm{CBAPC}$ 바인더와 인공사로 혼합 된 시험편의 내습성을 확인하기 위해 FT-IR (4600LE, Jasco, Japan) ATR 모드를 이용하여 CBAPC 바인더를 분 석하였다. 모든 샘플은 $4 \mathrm{~cm}^{-1}$ 의 분해능으로 $4000 ~ 500 \mathrm{~cm}^{-1}$ 범위로 100 회 스캔하여 스펙트럼을 얻었다. CBAPC 바인 더의 결정구조의 변화를 알아보기 위해 XRD (D8 Focus, Bruker, Germany)를 이용하여 경화 온도에 따른 CBAPC 바인더를 측정하였다. $\mathrm{XRD}$ 는 $\mathrm{Cu} \mathrm{K} \alpha$ 타겟 (Wavelength $1.5406 \AA), 40 \mathrm{kV}, 40 \mathrm{~mA}$ 의 조건에서 $5 \sim 80^{\circ}(2 \theta)$ 의 범위 에 걸쳐 $0.3 \%$ 의 스캔 속도로 측정되었다. $\mathrm{CBAPC}$ 바인 더와 인공사가 혼합된 시험편의 표면 결합 정도를 $\mathrm{FE}-$ SEM (SU8020, Hitachi, Japan)을 이용하여 확인하였다. $\mathrm{CBAPC}$ 바인더로 경화한 인공사의 표면을 백금 $(\mathrm{Pt})$ 으로 $15 \mathrm{~mA}, 180$ 초 조건으로 코팅하여 분석하였다. 


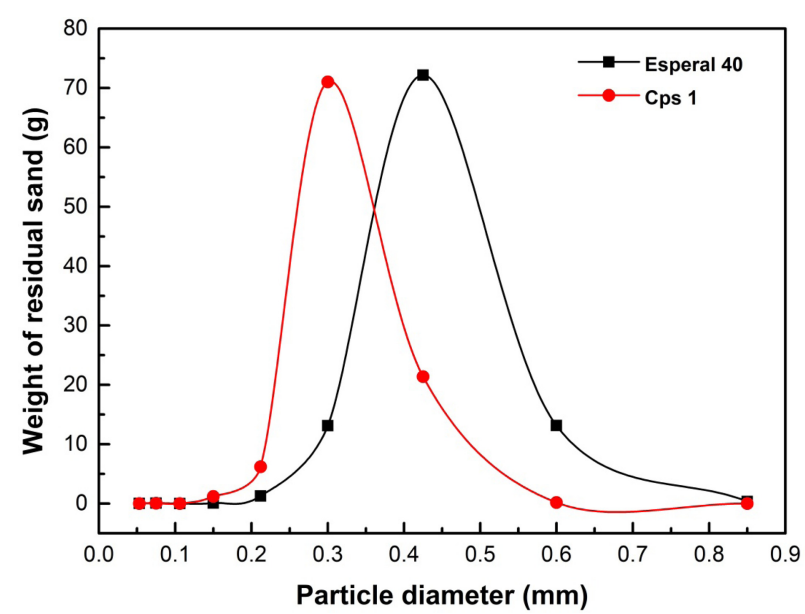

Fig. 4. Particle size distribution curves of artificial sands.

\section{3. 결과 및 고찰}

인공사 Esperal 40, $\mathrm{Cps}$ 1은 $\mathrm{XRF}$ 분석을 통해 시료의 성분을 비교한 결과를 표 1에 나타냈다. Esperal 40의 경 우 $\mathrm{Al}_{2} \mathrm{O}_{3}$ 와 $\mathrm{SiO}_{2}$ 함량은 71.87, $16.82 \mathrm{wt} \%$ 였으며, $\mathrm{Cps}$ 1 의 경우 $44.34,43.83 \mathrm{wt} \%$ 를 나타냈다.

그림 4는 인공사 Esperal $40, \mathrm{Cps}$ 1의 입도 분포 곡선을 나타냈다. 인공사의 입도는 특정 크기의 입자들이 집중적으로 분포되어 있으며, 입도 분포는 좁은 원뿔 모양으로 나타났다. 인공사 Esperal 40, Cps 1의 AFS GFN (american foundry society grain fineness number)는 30.35, 38.86을 나타냈다.

인공사의 입자 외관 및 표면 형상을 확인하기 위해 FE$\mathrm{SEM}$ 분석을 진행하였으며, 그 결과 그림 5 에 나타냈다. 인 공사는 규사와 달리 구상 입형을 가지나 Esperal 40, Cps 1 의 표면 형상은 서로 매끄럽거나 거침을 관찰하였다. Esperal
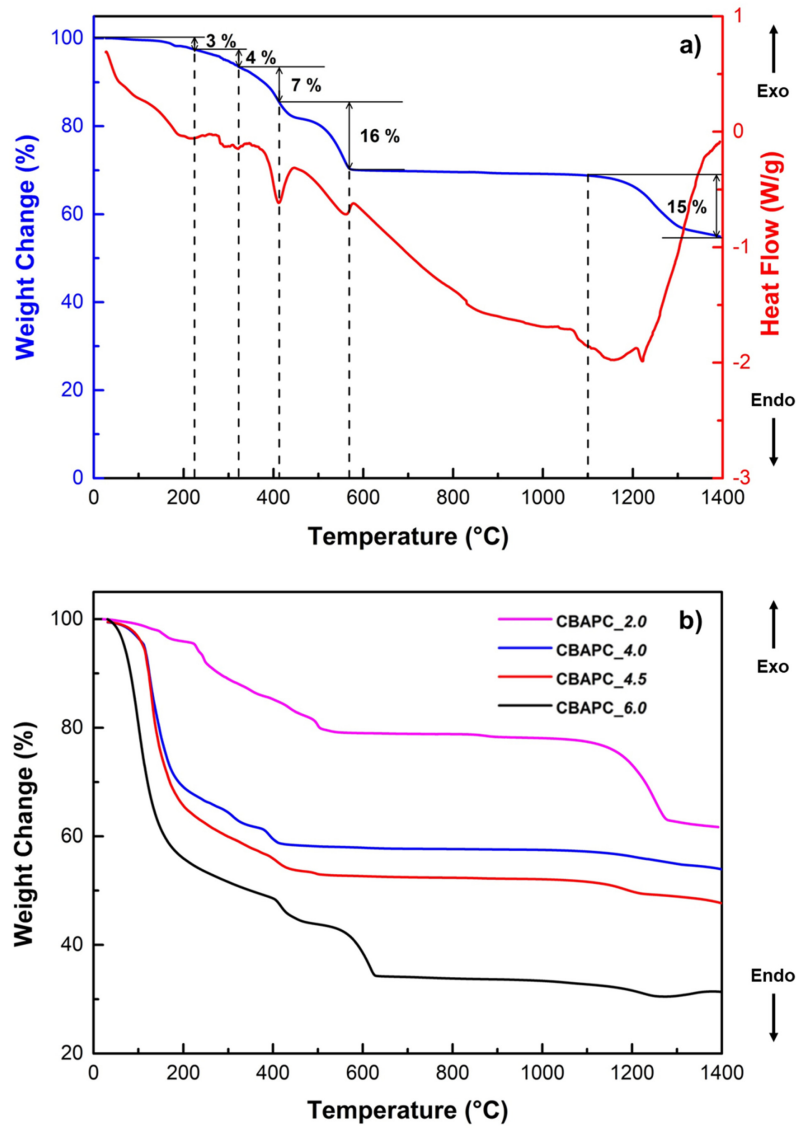

Fig. 6. TGA/DSC curves of CBAPC binder; (a) CBAPC 4.5 and (b) CBAPC_2.0, CBAPC_4.0, CBAPC_4.5, and CBAPC_6.0.

40의 표면은 불규칙한 다각형 모양으로 구성되어 있으며, $\mathrm{Cps}$ 1의 표면은 세세한 요철이 있는 것을 알 수 있다.

그림 6은 CBAPC_4.5의 TGA/DSC 곡선을 나타냈다. $\mathrm{TGA}$ 곡선은 중량 손실이 $50{ }^{\circ} \mathrm{C}$ 에서 시작되어 $570{ }^{\circ} \mathrm{C}$ 까지 중량 손실을 보였으며, $1220^{\circ} \mathrm{C}$ 까지 중량 손실이 없음을 보
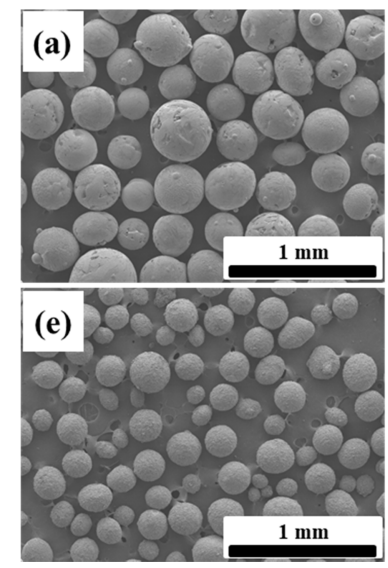
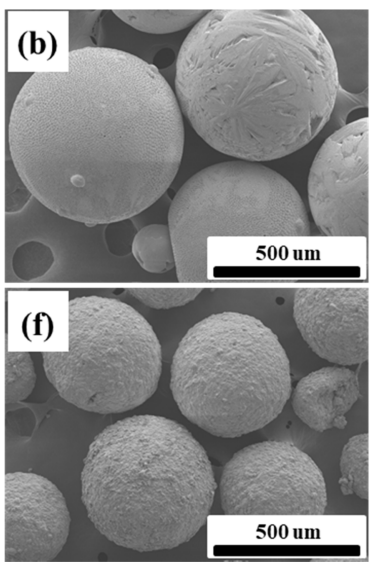
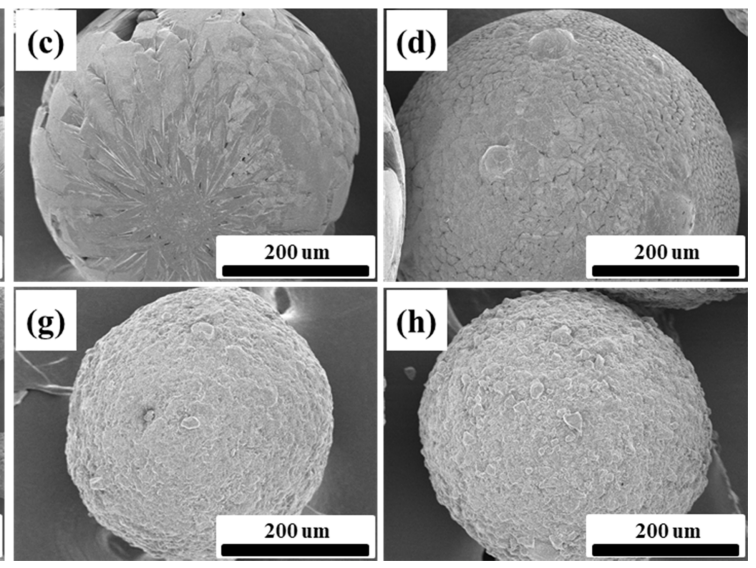

Fig. 5. FE-SEM images of artificial sands; (a-d) Esperal 40 and (e-h) Cps 1. 
Table 2. Phase transformation of aluminum phosphate binder

\begin{tabular}{cccc}
\hline Temp. $\left({ }^{\circ} \mathrm{C}\right)$ & Dominant phase & Candidate phase & Ref. \\
\hline 60 & $\mathrm{AlH}_{3}\left(\mathrm{PO}_{4}\right)_{2} \cdot 3 \mathrm{H}_{2} \mathrm{O}$ & & {$[16,21]$} \\
100 & $\mathrm{Al}\left(\mathrm{H}_{2} \mathrm{PO}_{4}\right)_{3}$ & $\mathrm{AlH}_{3}\left(\mathrm{PO}_{4}\right)_{2} \cdot 3 \mathrm{H}_{2} \mathrm{O}$ & {$[16,21]$} \\
150 & $\mathrm{Al}\left(\mathrm{H}_{2} \mathrm{PO}_{4}\right)_{3}$ & $\mathrm{AlPO}_{4}, \mathrm{AlH}_{3}\left(\mathrm{PO}_{4}\right)_{2} \cdot \mathrm{H}_{2} \mathrm{O}$ & {$[23,32]$} \\
200 & $\mathrm{AlH}_{3}\left(\mathrm{PO}_{4}\right)_{2}$ & $\mathrm{Al}_{2}\left(\mathrm{H}_{2} \mathrm{PO}_{4}\right)_{3}, \mathrm{AlH}_{2} \mathrm{P}_{3} \mathrm{O}_{10} \cdot 2 \mathrm{H}_{2} \mathrm{O}$ & {$[21,23]$} \\
250 & $\mathrm{AlH}_{2} \mathrm{P}_{3} \mathrm{O}_{10} \cdot 2 \mathrm{H}_{2} \mathrm{O}$ & $\mathrm{AlPO}_{4}, \mathrm{AlH}_{3}\left(\mathrm{PO}_{4}\right)_{2} \cdot 2 \mathrm{H}_{2} \mathrm{O}, \mathrm{Al}_{8} \mathrm{H}_{12}\left(\mathrm{P}_{2} \mathrm{O}_{7}\right)_{9}$ & This work \\
300 & $\mathrm{AlH}_{2} \mathrm{P}_{3} \mathrm{O}_{10} \cdot 2 \mathrm{H}_{2} \mathrm{O}, \mathrm{Al}\left(\mathrm{PO}_{3}\right)_{3}$ & $\mathrm{AlPO}_{4}, \mathrm{AlH}_{3}\left(\mathrm{PO}_{4}\right)_{2} \cdot 2 \mathrm{H}_{2} \mathrm{O}, \mathrm{Al}_{8} \mathrm{H}_{12}\left(\mathrm{P}_{2} \mathrm{O}_{7}\right)_{9}$ & This work \\
400 & $\mathrm{Al}\left(\mathrm{PO}_{3}\right)_{3}$ & $\mathrm{AlPO}_{4}, \mathrm{AlH}_{2} \mathrm{P}_{3} \mathrm{O}_{10} \cdot 2.5 \mathrm{H}_{2} \mathrm{O}$ & {$[21]$} \\
450 & $\mathrm{Al}\left(\mathrm{PO}_{3}\right)_{3}$ & $\mathrm{Al}_{2} \mathrm{P}_{6} \mathrm{O}_{18}, \mathrm{AlPO}_{4}$ & This work \\
500 & $\mathrm{Al}\left(\mathrm{PO}_{3}\right)_{3}$ & $\mathrm{Al}_{2} \mathrm{P}_{6} \mathrm{O}_{18}, \mathrm{AlPO}_{4}$ & {$[23,32]$} \\
550 & $\mathrm{Al}\left(\mathrm{PO}_{3}\right)_{3}$ & $\mathrm{Al}_{2} \mathrm{P}_{6} \mathrm{O}_{18}$ & {$[23]$} \\
700 & $\mathrm{Al}\left(\mathrm{PO}_{3}\right)_{3}$ & $\mathrm{AlPO}_{4}$ & {$[21]$} \\
800 & $\mathrm{Al}\left(\mathrm{PO}_{3}\right)_{3}$ & $\mathrm{AlPO}_{4}$ & This work \\
\hline
\end{tabular}

여준다. TGA 곡선에서 $220,320,410,570$ 및 $1220^{\circ} \mathrm{C}$ 부근에서 중량 손실 피크들을 확인하였다. 최초 $220{ }^{\circ} \mathrm{C}$ 까 지는 $\mathrm{CBAPC} 4.5$ 의 자유수 (free water) 증발로 $3 \%$ 의 중 량 손실을 보였으며, 이후 $320{ }^{\circ} \mathrm{C}$ 까지는 인산의 탈수 축합 반응에 의해 생성된 수분의 증발로 $4 \%$ 의 중량 손실을 보 였다. $320 \sim 410^{\circ} \mathrm{C}$ 와 $410 \sim 570{ }^{\circ} \mathrm{C}$ 에서는 $\mathrm{CBAPC} 4.5$ 의 상 변화 상응 온도에서 $7,16 \%$ 의 중량 손실을 각각 보인 것 을 확인하였다. $570 ~ 1100{ }^{\circ} \mathrm{C}$ 에서는 중량 손실이 거의 없었 으며 고온에서의 열 안정성이 우수한 세라믹 특성을 나타 냄을 알 수 있다. $1100{ }^{\circ} \mathrm{C}$ 이후에서 $\mathrm{CBAPC} 4.5$ 의 상변 화로 인한 $15 \%$ 의 중량 손실을 보였다.

알루미늄 포스페이트의 열적 특성은 많은 연구자들에 의 해 연구되었다. W. D. Kingery는 다양한 응용 분야에 사 용되는 포스페이트 결합 물질의 합성과 실온에서의 반응 역학에 대한 연구를 조사하였다 [18]. D. Chen et al.은 고온에서 알루미늄 포스페이트 바인더의 화학적 상변화에 대해 조사하였다 [21]. D. Chen et al.의 연구에 따르면 알 루미늄 포스페이트 바인더가 $200{ }^{\circ} \mathrm{C}$ 에 도달하면 $\mathrm{Al}\left(\mathrm{H}_{2} \mathrm{PO}_{4}\right)_{3}$ 이 주요 상이며, $250{ }^{\circ} \mathrm{C}$ 에서는 $\mathrm{AlH}_{2} \mathrm{P}_{3} \mathrm{O}_{10} \cdot 2 \mathrm{H}_{2} \mathrm{O}$ 와 $\mathrm{AlPO}_{4}$ (trigonal system)로 상변화되었다고 보고되었다. DSC 곡선 에서 5 개의 흡열 피크들이 존재하였으며, 관찰된 피크들은 주요한 상변화를 제안한다. 열처리 온도에 따른 알루미늄 포 스페이트 바인더의 가장 우세한 결합상은 표 2에 나타냈다 . $100 \sim 250{ }^{\circ} \mathrm{C}$ 에서의 중량 손실은 $\mathrm{AlH}_{2} \mathrm{P}_{3} \mathrm{O}_{10} \cdot 2 \mathrm{H}_{2} \mathrm{O}$ 상의 층 간수 (interlayer water) 손실과 일치하며, $250{ }^{\circ} \mathrm{C}$ 에서 강한 흡열 피크는 인산의 탈수 축합에 의한 가교 반응으로 발생 한다는 유사한 결과들이 문헌에 보고되었다 [21-23]. 이전 의 연구들을 통해 $470{ }^{\circ} \mathrm{C}$ 와 $800{ }^{\circ} \mathrm{C}$ 에서는 동일한
$\mathrm{Al}\left(\mathrm{PO}_{3}\right)_{3}$ 와 $\mathrm{AlPO}_{4}$ 상이 관찰되었는데, 알루미늄 포스페이 트는 $\mathrm{P} / \mathrm{Al}$ 몰 비에 따라 특성이 달라지고, 수산화 알루미늄 (Aluminum hydroxide)을 출발 물질로 사용한 것으로 보아 현재 연구와는 상이한 결과가 나타났다. 그러나 $470{ }^{\circ} \mathrm{C}$ 부 근에서 $\mathrm{Al}\left(\mathrm{PO}_{3}\right)_{3}$ 상 관찰로, 보고된 문헌들과 유사한 결과를 얻을 수 있었다. $570{ }^{\circ} \mathrm{C}$ 의 온도에서, $\mathrm{CBAPC} 4.5$ 의 잔류 질량은 기존 질량의 약 $30 \%$ 가 손실되었다. $450 \sim 550{ }^{\circ} \mathrm{C}$ 에 서 삼인산기 (triphosphate group)의 축합 시 발생하는 구 성수 (constitutional water) 1 분자 손실에 의한 중량 손실 과 $\mathrm{Al}\left(\mathrm{PO}_{3}\right)_{3}$ 상을 형성한다는 S. K. Rishi et al.의 연구 결과에 의해 확인되었다 [22].

그림 7은 열처리 온도에 따른 $\mathrm{CBAPC} 4.5$ 의 $\mathrm{XRD}$ 결 과를 나타냈다. 열처리 온도가 $260{ }^{\circ} \mathrm{C}$ 에서 $\mathrm{CBAPC} 4.5$ 의

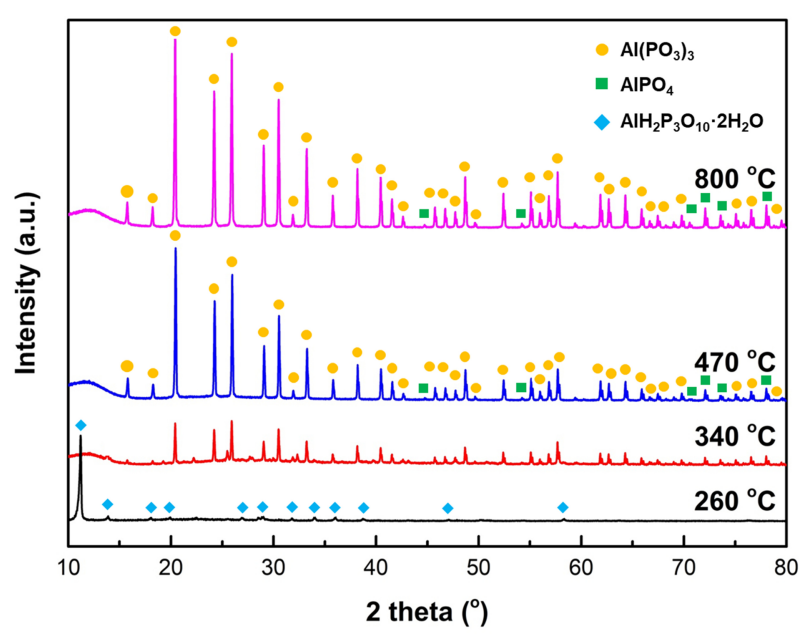

Fig. 7. XRD patterns of cured CBAPC_4.5. 


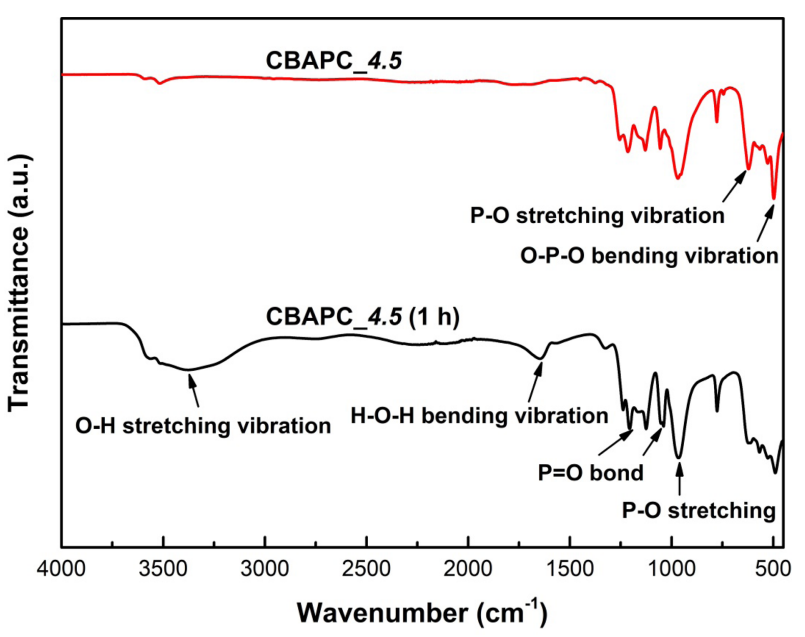

Fig. 8. FT-IR spectra of the CBAPC 4.5 and absorbed CBAPC 4.5 for $1 \mathrm{~h}$.

상은 $\mathrm{AlH}_{2} \mathrm{P}_{3} \mathrm{O}_{10} \cdot 2 \mathrm{H}_{2} \mathrm{O}$ (JCPDS No. 31-0017)로 확인하였 으며, 열처리 온도가 $260{ }^{\circ} \mathrm{C}$ 에서 $340{ }^{\circ} \mathrm{C}$ 로 증가하면서 CBAPC_4.5의 상은 $\mathrm{Al}\left(\mathrm{PO}_{3}\right)_{3}$ (JCPDS No. 13-264)와 $\mathrm{AlPO}_{4}$ (JCPDS No. 10-0423)인 것을 확인하였다. $470{ }^{\circ} \mathrm{C}$ 와 $800{ }^{\circ} \mathrm{C}$ 온도로 증가할수록 $\mathrm{Al}\left(\mathrm{PO}_{3}\right)_{3}$ 의 결정성이 증가함 을 관찰하였다 [24-26]. CBAPC_4.5의 XRD 분석 결과는 D. Chen et al.과 H. J. Han et al.의 연구 결과와 앞선 $\mathrm{TGA} / \mathrm{DSC}$ 분석 결과와 일치하는 것으로 확인되었다.

CBAPC_4.5의 화학적 구조와 내습성에 미치는 영향을 확인하기 위해 FT-IR 분석을 실시하였다. 흡습 전과 후의 CBAPC_4.5의 FT-IR 스펙트럼을 그림 8에 나타냈다. 1시 간 노출 (온도: $20{ }^{\circ} \mathrm{C}$, 상대습도: $30 \%$ ) 후 CBAPC_4.5 $(1 \mathrm{~h})$ 의 여러 흡수 피크가 관찰되었으며, CBAPC_4.5의 노출 시간이 경과함에 따라 $3400 \mathrm{~cm}^{-1}$ 에서 물 분자의 $\mathrm{O}-$ $\mathrm{H}$ 신축 진동 (stretching vibration)에 의해 넓고 강한 피 크를 확인하였다. 분자 내 존재하는 $\mathrm{OH}$ 기의 신축 진동 흡 수는 수소 결합에 의해 낮은 파수 (wavenumber)로 이동 하는 것을 확인하였으며, 이는 노출 시간이 경과함에 따라 CBAPC_4.5 내 흡습 현상이 발생하여 강도 감소에 영향을 미친 것으로 사료된다. 또한, $1645 \mathrm{~cm}^{-1}$ 에서 $\mathrm{H}-\mathrm{O}-\mathrm{H}$ 굽힘 진동 (bending vibration)으로 자유수가 존재함을 확인하였 다. 알루미늄 포스페이트 분말 입자는 일정량의 폐쇄 기공 이 존재하여 수분을 흡수한 것으로 판단된다 [27,28]. 494, $714 \mathrm{~cm}^{-1}$ 에서의 특징적인 피크들은 O-P-O 굽힘 진동 및 $\left(\mathrm{PO}_{4}\right)^{3-}$ 의 $\mathrm{P}-\mathrm{O}$ 신축 진동에 의해 각각 관찰되었다. CBAPC_4.5의 노출 시간이 경과함에 따라 $494,714 \mathrm{~cm}^{-1}$ 에서의 O-P-O, P-O 밴드가 감소하였다.

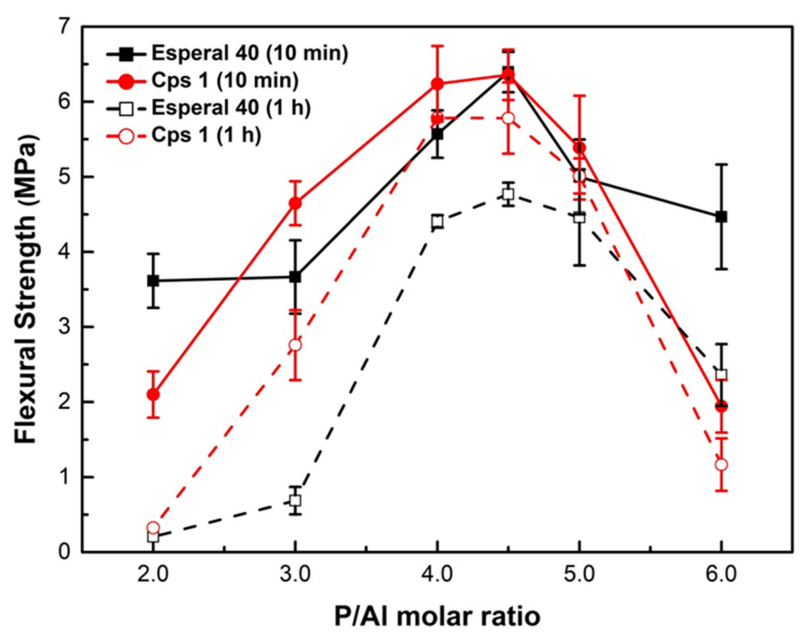

Fig. 9. Effect of $\mathrm{P} / \mathrm{Al}$ molar ratio on flexural strength of CBAPC_ 4.5 coated artificial sands.

다양한 $\mathrm{P} / \mathrm{Al}$ 몰 비를 가지는 $\mathrm{CBAPC}$ 바인더의 항절 강 도를 측정하였으며, 그 결과 그림 9에 나타냈다. CBAPC 바인더와 인공사 Esperal $40, \mathrm{Cps} 1$ 을 사용하여 제조한 시험편은 항온 항습기에서 10 분, 1 시간 노출 $\left(\right.$ 온도: $20^{\circ} \mathrm{C}$, 상대습도: $30 \%$ ) 후 항절 강도를 측정하였다. $\mathrm{CBAPC}$ 바 인더의 $\mathrm{P} / \mathrm{Al}$ 몰 비가 4.5 일 때, 인공사 Esperal $40, \mathrm{Cps}$ 1 에서 최대 강도를 나타내었으며, $\mathrm{P} / \mathrm{Al}$ 몰 비가 2.0 에서 4.5 로 증가함에 따라 10 분 강도는 $3.61,2.10 \mathrm{MPa}$ 에서 $6.40,6.36 \mathrm{MPa}$ 로 증가하였다. $\mathrm{CBAPC}$ 바인더의 $\mathrm{P} / \mathrm{Al}$ 몰 비가 4.5 에서 6.0 으로 증가함에 따라 10 분 강도는 4.11 , $1.94 \mathrm{MPa}$ 로 감소하였다. $260^{\circ} \mathrm{C}$ 에서 경화한 CBAPC_4.5의 구조는 $\mathrm{AlH}_{2} \mathrm{P}_{3} \mathrm{O}_{10} \cdot 2 \mathrm{H}_{2} \mathrm{O}$ 였으며, 화학양론적으로 알루미늄 포스페이트 기반의 바인더는 인산과 알루미늄 염의 액체 용액, $\mathrm{Al}\left(\mathrm{PO}_{3}\right)_{3}$ 및 $\mathrm{AlPO}_{4}$ 같은 고체상을 형성하기 위해 $\mathrm{CBAPC}$ 바인더의 $\mathrm{P} / \mathrm{Al}$ 몰 비가 일반적으로 3.0 보다 높아 야 안정하고 우수한 접착성을 보이게 된다 [20]. 알루미늄 포스페이트는 탈수로 인해 인이 산소를 공유하는 P-O-P 결합을 갖는 고분자가 형성되고, 이 고분자가 $\mathrm{CBAPC}$ 바 인더의 접착성을 갖게 된다. 그러나, CBAPC_4.5에서 최대 강도를 나타내었으며, 그 외의 $\mathrm{P} / \mathrm{Al}$ 몰 비에서는 강도가 감소하는 경향이 관찰되었다.

$\mathrm{CBAPC}$ 바인더의 $\mathrm{P} / \mathrm{Al}$ 몰 비에 따른 $\mathrm{TGA}$ 곡선을 보 면, CBAPC_2.0은 고형분의 함량이 가장 많고, 인산의 함 량이 가장 적기 때문에 $220 \sim 240{ }^{\circ} \mathrm{C}$ 온도 범위에서의 강열 감량이 가장 적은 것을 확인하였다. 강열 감량은 CBAPC_2.0, CBAPC_4.0, CBAPC_4.5 및 CBAPC_6.0 순으로 적었으며, CBAPC_6. 0 은 인산의 함량이 많아 저온 
구간에서 가장 급격한 중량 손실 패턴을 보였다. $220^{\circ} \mathrm{C}$ 는 상전이 온도이기 때문에 $260^{\circ} \mathrm{C}$ 에서 열처리하였으며, 그 온 도 범위에서의 중량 손실이 비교적 적은 CBAPC_4.5는 열 안정성이 우수하여 강도 증진에 영향을 미친 것으로 사 료된다. CBAPC 바인더의 P/Al 몰 비가 3.0 이하일 때, 이상적으로 반응하여 결정이 형성되기 시작해야 하지만 바 인더 내 결정이 이미 형성된 것을 알 수 있었다. 알루미늄 포스페이트가 인산에 모두 용해되지 않아 바인더로써의 접 착성이 낮아져 강도가 감소됨을 확인하였다. CBAPC 바인 더의 $\mathrm{P} / \mathrm{Al}$ 몰 비가 4.5 일 때, 추가적인 인산의 함량으로 용해가 되기 시작하여 효과적인 액상 분위기를 만들고 우 수한 접착성을 가져 높은 강도를 발현하는 것을 관찰하였 다. $\mathrm{CBAPC}$ 바인더의 $\mathrm{P} / \mathrm{Al}$ 몰 비가 4.5 이상일 때, 알루 미늄 포스페이트가 인산에 모두 용해되지만 반응에 관여하 지 않은 다량의 인산 함량으로 인해 흡습성이 증가하여 강 도가 감소됨을 확인하였다. CBAPC 바인더 내 남아있는 여분의 인산은 반응 중에 $\mathrm{H}_{2}$ 가스를 형성시킨다. $\mathrm{H}_{2}$ 가스 는 인공사 입자 표면에서 기공률 (porosity)을 증가시키며 $\mathrm{CBAPC}$ 바인더의 결합력이 저하됨을 알 수 있다. 규사와 인공사의 다른 화학적 조성이 CBAPC 4.5와 결합되어 우 수한 접착성을 나타냈다. 인공사는 규사에 비해 $\mathrm{Al}_{2} \mathrm{O}_{3}$ 의 함량이 현저하게 많기 때문에 여분의 인산이 인공사의 $\mathrm{Al}_{2} \mathrm{O}_{3}$ 와 반응하여 결합력이 증가한 것으로 보인다. 인공사 의 $\mathrm{Al}_{2} \mathrm{O}_{3}$ 성분과 $\mathrm{CBAPC}$ 바인더의 혼합 과정에서 추가적 인 반응에 의해 $\mathrm{CBAPC}$ 바인더의 $\mathrm{P} / \mathrm{Al}$ 몰 비가 4.5 에서 최대 강도를 보이는 것을 관찰하였다. 그러나, 시험편의 강 도는 동일한 조건 (온도: $20^{\circ} \mathrm{C}$, 상대습도: $30 \%$ )에서 노출 시간이 10 분에서 1 시간으로 경과함에 따라 감소하였다 [29]. FT-IR 결과, 노출 (온도: $20^{\circ} \mathrm{C}$, 상대습도: $30 \%$ ) 시 간이 경과함에 따라 $3400,1645 \mathrm{~cm}^{-1}$ 에서 -OH 피크가 넓 어짐을 확인하였으며, CBAPC 4.5 내 생성된 수분의 흡습 으로 시험편의 강도 감소에 영향을 미침을 알 수 있다.

그림 10 은 인공사 Esperal $40, \mathrm{Cps} 1$ 에 코팅된 CBAPC_4.5로 제조된 시험편을 동일한 노출 조건 (온도: $20{ }^{\circ} \mathrm{C}$, 상대습도: $30 \%$ )에서 노출 시간에 따른 중량 변화를 나타냈다. 노출 시간 10 분 후에는 Esperal $40, \mathrm{Cps} 1$ 의 시험편 중량은 $2.0,0.3 \%$ 증가하였다. 10 분에서 50 분으로 경과함에 따라 시험편의 중량은 $2.0,1.4 \%$ 증가하였으며, 50 분에서 60 분으로 경과함에 따라 시험편의 중량은 0.7 , $0.1 \%$ 로 증가하였다. 인공사에 따라 흡습량이 다름을 확인 하였으며, Esperal 40이 Cps 1보다 흡습량이 많은 것을 확인하였다. 이는 두 인공사의 다른 화학적 조성에 기인된 것으로 판단된다.

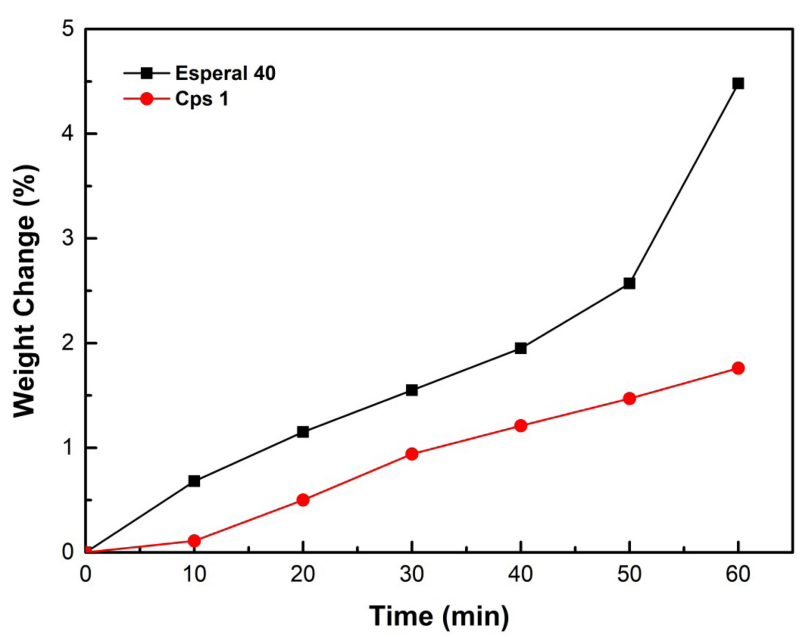

Fig. 10. Weight change during specimen fabricated using CBAPC_4.5 coated artificial sands.

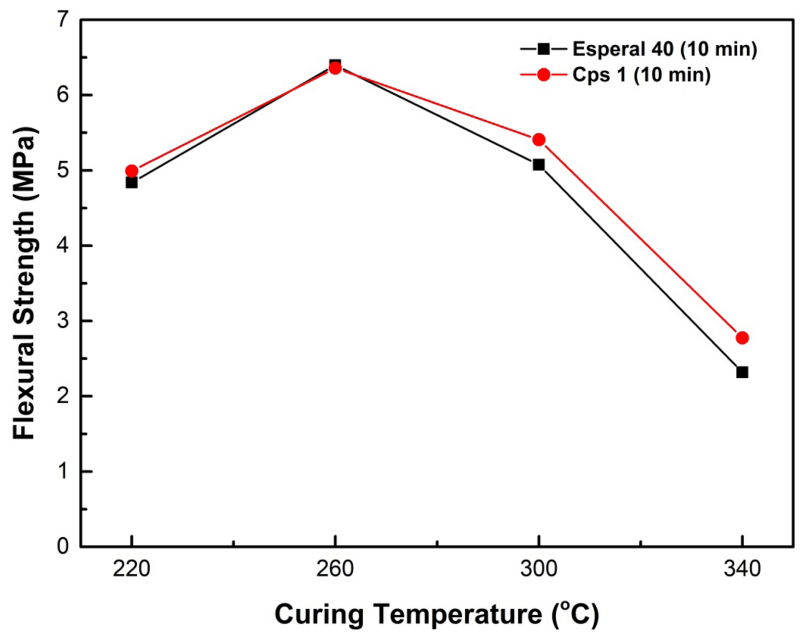

Fig. 11. Effect of curing temperature on flexural strength of CBAPC_ 4.5 coated artificial sands.

그림 11은 경화 온도에 따른 인공사 Esperal $40, \mathrm{Cps}$ 1 에 코팅된 CBAPC_4.5로 제조된 시험편의 항절 강도 분 석 결과를 나타냈다. Esperal $40, \mathrm{Cps} 1$ 은 $260^{\circ} \mathrm{C}$ 에서 최 대 강도를 나타내었으며, 경화 온도가 $220{ }^{\circ} \mathrm{C}$ 에서 $260{ }^{\circ} \mathrm{C}$ 로 증가함에 따라 시험편의 항절 강도는 $4.84,4.99 \mathrm{MPa}$ 에서 $6.40,6.36 \mathrm{MPa}$ 로 증가하였다. CBAPC_4.5를 $100{ }^{\circ} \mathrm{C}$ 에서 열처리 시 $\mathrm{Al}\left(\mathrm{H}_{2} \mathrm{PO}_{4}\right)_{3}$ 구조를 형성하며, $200 \sim 280{ }^{\circ} \mathrm{C}$ 에서 $\mathrm{Al}\left(\mathrm{H}_{2} \mathrm{PO}_{4}\right)_{3}$ 의 탈수 축합 반응에 의해 형 성된 $\mathrm{AlH}_{2} \mathrm{P}_{3} \mathrm{O}_{10} \cdot 2 \mathrm{H}_{2} \mathrm{O}$ 구조는 비수용성 유리 구조로써 기 계적 강도와 내습성이 우수하여 시험편의 강도에 큰 영향 을 미쳤을 것이라 판단된다. 경화 온도가 $260{ }^{\circ} \mathrm{C}$ 에서 $340{ }^{\circ} \mathrm{C}$ 로 증가함에 따라 시험편의 항절 강도는 $2.32,2.77$ 

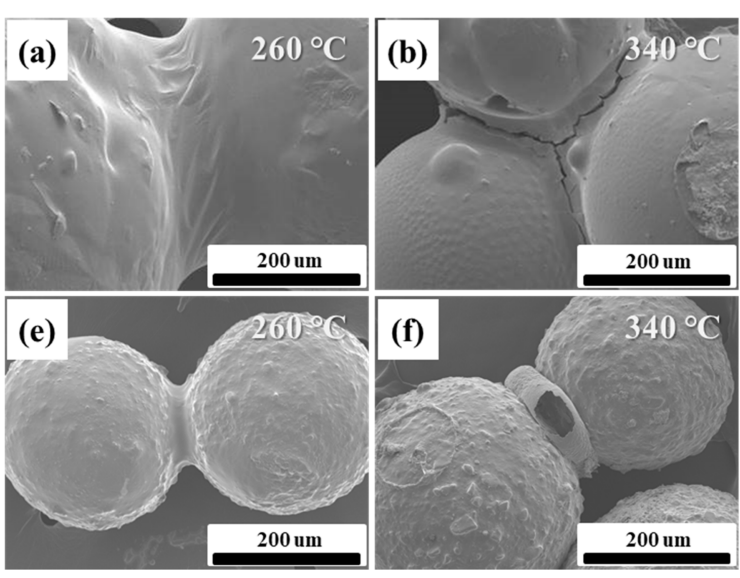
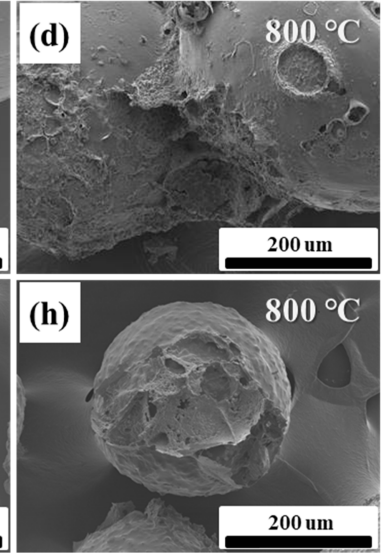

Fig. 12. FE-SEM images of cured CBAPC_4.5 coated artificial sands; (a-d) Esperal 40 and (e-h) Cps 1.

$\mathrm{MPa}$ 로 급격히 감소하였다. 고온으로 갈수록 인공사와 CBAPC_4.5간 결합에 영향을 미치는 구조가 분해되어 표 면으로부터 CBAPC_4.5의 코팅층이 얇아져 강도가 감소하 였다.

그림 12는 경화 온도에 따른 인공사 Esperal 40, Cps 1 에 코팅된 $\mathrm{CBAPC} 4.5$ 로 제조된 시험편의 $\mathrm{FE}-\mathrm{SEM}$ 분석 을 나타냈다. $260{ }^{\circ} \mathrm{C}$ 에서 경화된 시험편은 $\mathrm{CBAPC} 4.5$ 가 인공사 입자 표면에 균일하게 코팅되었으며, 인공사 입자 사이를 연결하는 구조체의 가교 결합 (bonding bridges)은 매끄럽고 조밀한 구조를 확인할 수 있었다. 가교 결합은 가 열 탈수에 의한 소립자간의 응집 및 융합에 의해 평활화를 거쳐 균질화된다. 인공사 입자 사이에 코팅된 CBAPC_4.5 의 함량이 많을수록 시험편 내부까지 반응이 균질화되며 입자 표면의 균열 (crack)과 공극 (hole)을 방지하여 높은 강도를 발현할 수 있다 [10]. 경화 온도를 $260{ }^{\circ} \mathrm{C}$ 에서 340,470 및 $800^{\circ} \mathrm{C}$ 로 증가시켰을 때, 열 분해로 인해 CBAPC_4.5의 결정수가 기화되어 인공사 입자 사이의 가 교 결합이나 표면은 큰 균열과 많은 공극이 형성됨을 확인 하였다 [30,31]. 그 결과, CBAPC_4.5에 코팅된 인공사의 표면이 크게 손상되었으며, 균열과 공극이 CBAPC_4.5의 결합 강도 저하에 영향을 미쳤으며 가교 결합은 온도 변화 에 영향을 받음을 알 수 있다.

그림 13은 경화 시간에 따른 인공사 Esperal $40, \mathrm{Cps}$ 1 에 코팅된 CBAPC_4.5로 제조된 시험편의 항절 강도 분 석 결과를 나타냈다. Esperal $40, \mathrm{Cps} 1$ 은 $260{ }^{\circ} \mathrm{C}$ 에서 10 분 경화 시 최대 강도 $6.40,6.36 \mathrm{MPa}$ 를 나타냈다. 경화 시간이 5분에서 7분으로 경과함에 따라 CBAPC_4.5 내 존재하는 많은 함량의 인산을 증발시키기 위한 건조 시간 이 부족하여 시험편의 제조가 어려운 경향을 관찰하였다.

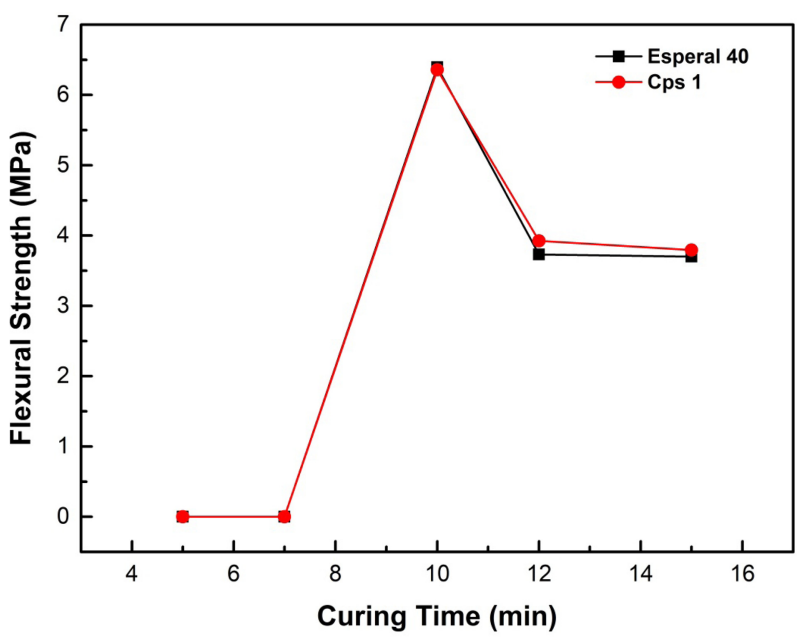

Fig. 13. Effect of curing time on flexural strength of CBAPC 4.5 coated artificial sands.

경화 시간이 10 분에서 15 분으로 경과함에 따라 시험편의 강도는 $42,41 \%$ 로 각각 감소하였다. 이는 경화 과정에서 CBAPC_4.5 내 여분의 인산을 완전히 증발시켰으나, 인공 사와 $\mathrm{CBAPC} 4.5$ 간의 코팅층이 얇아져 시험편의 강도가 감소하였다.

\section{4. 결 론}

인산과 알루미늄 포스페이트 $(\mathrm{P} / \mathrm{Al})$ 의 몰 비와 열처리 온도에 따른 $\mathrm{CBAPC}$ 바인더를 합성하였으며, 인공사 Esperal 40, Cps 1을 사용하여 시험편을 제조 후 $\mathrm{P} / \mathrm{Al}$ 몰 비, 경화 온도 및 경화 시간에 따라 시험편의 항절 강도를 측정하였다. 인공사 Esperal 40, $\mathrm{Cps}$ 1은 $\mathrm{CBAPC}$ 바인더 
의 $\mathrm{P} / \mathrm{Al}$ 몰 비가 4.5 , 경화 온도가 $260{ }^{\circ} \mathrm{C}$, 경화 시간이 10 분일 때, 시험편의 최대 강도 $6.40,6.36 \mathrm{MPa}$ 를 나타냈 다. TGA/DSC 분석을 통해 CBAPC_4.5의 220,320 , $410,570{ }^{\circ} \mathrm{C}$ 및 $1220{ }^{\circ} \mathrm{C}$ 에서 상변화가 발생함을 확인하였 다. $\mathrm{CBAPC} 4.5$ 는 그 외의 $\mathrm{P} / \mathrm{Al}$ 몰 비를 갖는 $\mathrm{CBAPC}$ 바인더에 비해 저온 구간에서의 우수한 열 안정성을 가져 중량 손실이 가장 적었다. 인공사의 종류에 따라, 시험편의 1 시간 노출 후의 강도가 다름을 확인하였으며, 인공사의 화 학적 조성이 영향을 미치는 것을 확인하였다. 경화 온도에 따라 $\mathrm{CBAPC}_{-}$.5의 상변화로 인해 강도가 달라짐을 확인 하였으며, $260{ }^{\circ} \mathrm{C}$ 에서 형성된 $\mathrm{AlH}_{2} \mathrm{P}_{3} \mathrm{O}_{10} \cdot 2 \mathrm{H}_{2} \mathrm{O}$ 구조는 비 수용성 유리구조로써 기계적 강도와 내습성이 우수하게 나 타났다. CBAPC_4.5 내 존재하는 여분의 인산을 건조시키 기 위한 경화 시간은 10 분이였으며, 경화 온도 및 경화 시간에 따라 CBAPC_4.5와 인공사 표면의 결합 구조가 변화하여 항절 강도에 영향을 미친 것을 확인하였다.

\section{감사의 글}

본 연구는 2019년도 산업통상자원부 및 산업기술평가관 리원 (KEIT) 연구비 지원(200000126)과 산업통상자원부의 산업기술혁신사업(10067386)의 지원을 받았으며, 한국생산 기술연구원 기관주요사업 “2019년 수요기반생산기술실용 화사업(4/4) (KITECH EO-19-0140)"의 지원으로 수행한 연구입니다.

\section{REFERENCES}

1. J. T. Fox, F. S. Cannon, N. R. Brown, H. Huang, and J. C. Furness, Int. J. Adhes. Adhes. 34, 38 (2012).

2. Y. Inoue, Y. Motoyama, H. Takahashi, K. Shinji, and M. Yoshida, J. Mater. Process. Tech. 213, 1157 (2013).

3. P. M. Geffroy, M. Lakehal, J. Goni, E. Beaugnon, and J. F. Silvain, J. Mater. Process. Tech. 209, 4103 (2009).

4. B. E. Brooks, C. Beckermann, and V. L. Richards, J. Cast. Metal. Res. 20, 177 (2007).

5. S. Chaudhari and H. Thakkar, Int. J. Eng. Res. Appl. 4, 615 (2014).

6. S. Wen, Q. Shen, Q. Wei, C. Yan, W. Zhu, Y. Shi, J. Yang, and Y. Shi, J. Mater. Process. Tech. 225, 93 (2015).

7. K. Kosuge, M. Sunaga, R. Goda, H. Onodera, and T. Okane, Mater. Trans. 59, 1784 (2018).

8. L. Xia, Y. Zhang, and J. Huang, Adv. Mater. Res. 97-101, 979 (2010).
9. L. Xia, J. Huang, and Y. Zhang, Adv. Mater. Res. 189-193, 3828 (2011).

10. G. H. Cho, E. H. Kim, and Y. G. Jung, J. Kor. Ceram. Soc. 53, 541 (2016).

11. Y. B. Ryu and M. S. Lee, Korean J. Met. Mater. 56, 72 (2018).

12. J. M. Chiou and D. D. L. Chung, J. Mater. Sci. 28, 1435 (1993).

13. H. Polzin, Inorganic Binders for Mould and Core Production in the Foundry, 1st ed., Fachverlag Schiele and Schön GmbH, Germany (2014).

14. J. M. Chiou, B. Y. Wei, and C. M. Chen, J. Mater. Eng. Perform. 2, 383 (1993).

15. A. S. Wagh and S. Y. Jeong, J. Am. Ceram. Soc. 86, 1838 (2003).

16. A. S. Wagh, Chemically Bonded Phosphate Ceramics, 2nd ed., Elsevier, United State (2004).

17. J. H. Morris, P. G. Perkins, A. E. A. Rose, and W. E. Smith, Chem. Soc. Rev. 6, 173 (1977).

18. W. D. Kingery, J. Am. Ceram. Soc. 33, 239 (1950).

19. T. Finch and J. H. Sharp, J. Mater. Sci. 24, 4379 (1989).

20. D. D. L. Chung, J. Mater. Sci. 38, 2785 (2003).

21. D. Chen, L. He, and S. Shang, Mat. Sci. Eng. A 348, 29 (2003).

22. S. K. Rishi, B. M. Kariuki, N. J. Checker, J. Godber, and A. J. Wright, Chem. Commun. 7, 747 (2006).

23. H. J. Han and D. P. Kim, J. Sol-Gel Sci. Techn. 26, 223 (2003).

24. M. Vippola, J. Keränen, X. Zou, S. Hovmöller, T. Lepistö, and T. Mäntylä, J. Am. Ceram. Soc. 83, 1834 (2000).

25. Y. Muraoka and K. Kihara, Phys. Chem. Miner. 24, 243 (1997).

26. L. Pauling and J. Sherman, Z. Krist. Cryst. Mater. 96, 481 (1937).

27. C. M. Chen and J. M. Jehng, Catal. Lett. 85, 73 (2003).

28. A. M. Saat, A. A. Malik, A. Azmi, M. F. A. Latif, N. E. Ramlee, and M. R. Johan, J. Eng. Appl. Sci. 12, 1237 (2017).

29. W. Jina, F. Zitian, Z. Xiaolei, and P. Di, China foundry 6, 191 (2009).

30. L. Yue, S. Tongfei, C. Bing, and L. Yaqiang, Constr. Build. Mater. 91, 126 (2015).

31. N. Liu and B. Chen, Constr. Build. Mater. 121, 354 (2016).

32. P. L. Zhuravleva, N. S. Kitaeva, Y. M. Shiryakina, and A. A. Novikova, Russ. J. Appl. Chem. 89, 367 (2016). 